\title{
Outsourced Services, Supervision of Contracts and Labor Liabilities: Case Study UNIR From 2015 to 2019
}

\author{
Aline Cristina Helfenstein ${ }^{1}$, Douglas Fernando Batista Neis ${ }^{1}$, Flávia Regina Alves de Hungria Folador ${ }^{1}$, Marlene \\ Valério dos Santos Arenas ${ }^{1}$, Rafael Vicente Martins dos Reis ${ }^{1} \&$ Francisco Alexandre Belinassi Paim ${ }^{1}$ \\ ${ }^{1}$ Public Administration, Brazil \\ Correspondence: Douglas Fernando Batista Neis, Public Administration, Brazil.
}

Received: September 9, 2020

Accepted: November 27, 2020

Online Published: December 3, 2020

doi:10.5430/ijba.v12n1p22

URL: https://doi.org/10.5430/ijba.v12n1p22

\begin{abstract}
This article aims to identify the monetary amounts spent by Fundação Universidade Federal de Rondônia (UNIR), with Labor Court due to administrative failures during the supervision of outsourced service contracts. It is a case study, with qualitative research, with documentary analysis of the decisions, sentences and judgments delivered in the processes. After the analysis of 68 (sixty-eight) cases in which UNIR appeared in the passive pole, categories were identified for the classification of the cases. It was found that there was a reduction in the number of lawsuits against UNIR after the Labor Reform and 21 (twenty-one) lawsuits were identified in which UNIR was ordered to pay labor indemnities or the contracted companies signed labor agreements, causing the public agency to be obliged to make payments through Small Value Requests (RPV), or Precatories, deriving from failures in internal controls and management contracts at Fundação Universidade Federal de Rondônia (UNIR).
\end{abstract}

Keywords: joint liability, supervision of contracts, outsourced service

\section{Introduction}

Fundação Universidade Federal de Rondônia (UNIR) has an infrastructure with several campuses and administrative units that need maintenance. Due to the need to reduce personnel costs and optimize the workforce, the Brazilian public administration, in general, has been concentrating its forces on basic services, in other words, those aimed directly at the population, such as education, health and safety, making that the media services are made available to the market through bidding processes, that is, hiring companies to provide these services, which are now called outsourced services.

The services provided for outsourcing are mostly cleaning and security and the market has companies specialized in providing services to public agencies. Although the Law of Bids and Contracts no. 8,666/1993 and its amendments establishes that the public administration is not responsible for the payment of eventual personnel expenses, arising from outsourced service contracts, the Labor Court must verify whether, in a specific case, there was an omission on the part of the contracting authority during the supervision of the contract.

The need to monitor the working relationships of the companies hired with their employees requires constant monitoring by the internal control systems of the agencies, and it should be regulated, from the basic project / term of reference, that are the basis for the preparation of the bidding notice, and the contract between the public agency and the winner of the bid.

The eventual absence of supervision of administrative contracts may result in a labor liability for the public agency, causing the public agency to be obliged to make payments through Small Value Requests (RPV), or Precatories, reducing the payment and investment capacity of other demands of the population. So, does Fundação Universidade Federal de Rondônia (UNIR) satisfactorily inspect its outsourced service contracts in order to avoid a labor liability due to judicial convictions?

Thus, supported by the Theory of New Public Management, the Theory of Transaction Costs and Theory of Processes, the preparation of this research has as a main objective to identify the monetary values spent by Fundação Universidade Federal de Rondônia (UNIR) with the Labor Court due to administrative failures in the supervision of outsourced service contracts. 
As specific objectives, the research aims to identify the amount of resources spent by UNIR in the payment of labor indemnities in the period from January 1, 2015 to December 31, 2019 (i); to list any indirect costs provided by the need to defend UNIR (ii); to verify the impact of the Labor Reform on the number of lawsuits against the UNIR (iii).

Such a task is justified by the need for improvement and optimization of control and management techniques by public agencies, especially UNIR, to improve procedural flows, internal control systems and management of administrative contracts, avoiding the payment of labor indemnities and the need for greater security, transparency and efficiency in outsourced service processes.

This research is composed of this introduction, conceptual theoretical review that deals with the Theory of New Public Management (NGP), Contractor's Responsibility, methodological procedures, Results and discussion of data, and finally, final considerations.

\section{Theoretical Reference}

The Theory of New Public Management (NGP) arises from the need to be applied in the public service, the instruments that eliminate the common bureaucratic obstacles in government management. Among the boosting factors that characterize this theory, it is highlighted, among other ones, the ineptitude of effective management measures and those inherent to the effectiveness of managed processes (JÚNIOR, NEVES, GUIMARAES, 2017).

Both in large organizations, such as the Federal, State and Municipal Governments, in addition to Foundations and Authorities, the aim is to develop procedural flows that minimize the creation of functional barriers. These barriers come from the specialization of work and individual efficiency, which causes the institution to break the systemic procedural flow, in which the processes are thought for the whole and not for specific sectors.

These individual specialization processes can create functional barriers, which would impede the due process flow, and these subdivisions become pilling up in the different hierarchical levels of departments, managements, secretariats, ministries, dividing the process into small flows, functional barriers that, in turn, they give rise to islands of knowledge, losing efficiency, hindering the delivery of services to the community as highlighted by Sordi (2017).

In order to get rid of the bureaucratic trap, classified by Sordi (2017) as isolated islands of knowledge, institutions must be guided in the search for developing systemic processes, so that the various hierarchical levels are integrated in the activities and work in a collaborative way, where each department / agency can complement the action of the other and not just commit to the activities inherent to their functions.

A mature, high-performance procedural flow allows the various sectors to seek the development of activities in an improved way, focusing on the effectiveness of the work. Thus, as advocated by Sordi (2017), the procedural flow must be interactive, where the departments can analyze and boost the processes for the department / agency that will effectively contribute to the development of the procedure and not just to comply with a predetermined bureaucratic flow.

In this sense, during this interactive procedural flow among the various sectors that make up an institution, control systems must be established to verify the correct course and path to be followed throughout the procedural flow. In turn, this control is not conditioned to a specific department, sector, or organization, but it must be carried out by the stakeholders who are called upon to intervene in the process (SORDI, 2017).

Therefore, procedural interactivity must be based on the coalition of forces of the different actors in the process, in order to verify the correct procedure of their activities, where the agents can develop in their attributions the autonomy to manage the processes, contemplating all the activities developed previously, in order that eventual mistakes can be quickly resolved, searching for a positive result for the institution, resulting in the delivery of an effective and efficient service to society (SORDI, 2017).

The failure to adopt effective procedural flows generates costs that need management and contracts to be fulfilled, under penalty of sanctions in case of non-compliance. In this administrative context, regulated by Law 8,666 / 93, there are facts that can escape the rule, which can be subdivided into two categories. The first category is linked to the behavior of the parties, who may submit to opportunistic attitudes. The second category, on the other hand, is linked to the limitation of total information about the contracted object, which inhibits decision making, being able to maximize the efficiency of the contract. (LIMA, RUFNO, MACHADO, 2019).

Transaction costs such as planning, monitoring and inspection arise from opportunism and limited information, which are implemented to ensure compliance with contractual clauses and in order to resolve conflicts between the parties motivated by opportunism or limitation of the information. Such transaction costs are recurrent in contracts between 
private companies and government agencies. From this contractual relationship, opportunism and insufficient information are fertile ground for corruption to be installed (LIMA, RUFNO, MACHADO, 2019).

Among the range of costs involved in the transactions of public entities and service providers, this article highlights the cost of eventual legal claims filed by employees of companies providing outsourced services, the most common being cleaning and security services for buildings public.

Outsourcing arose from the need for specialization of work, therefore, public agencies focused their activities on core services, passing on to the private sector, middle services, which occur through the hiring of a company to provide services to another institution, being paid by defined values in contracts, which must, for public institutions, obey the Laws of Bidding and Contracts (BARCELLOS and NOGUEIRA, 2019).

However, as highlighted by Pozzetti and Wolff (2019), public agencies may be called upon to respond alternatively if the hired company to provide outsourced services does not honor payments to its employees. Although Law No. $8,666 / 93$ removes subsidiarity in the article 71 from the public agency, the public institution can be condemned if it doesn't implement article 58 of the aforementioned law, in which it confers to the public power the prerogative to inspect the services provided by the hired entities.

Therefore, it is understood that if the public entity doesn't carry out the due inspection of the services provided by the outsourced company, incurs inefficient contract management or allows to ensure the labor rights of the outsourced employees, it violates the principle of human dignity and the social valorization of the work, with the guilt in vigilando on the part of the entity, being subject to subsidiary condemnation, in order to honor the unfulfilled payments by the hired company to perform the outsourced services, according to Precedent no. 331 of the TST.

When the public entity is condemned to respond alternatively, if the first convicted (hired company) does not bear the legal costs, it may have reversed the execution of the amounts due against it and be obliged to pay it, which will be given by Small Claims (RVP) or Precatory, depending on the amount of the sentence (POZZETTI and WOLFF, 2019).

After listing the factors to be developed for an efficient procedural flow, within a doctrine of specialization of work, optimization of resources, there is a need for efficient and effective procedural controls, in order to rule out the possibility of subsidiary convictions, arising from labor proceedings to public entities.

Next, it will be described the methodological procedures of the research carried out, identifying the monetary amounts spent by Fundação Universidade Federal de Rondônia (UNIR), with the Labor Court, due to administrative failures in the supervision of outsourced contracts.

\section{Methodological Procedures}

According to Creswell and Clark (2013), the research is based on the collection, analysis, interpretation and report of the object to be researched and based on the collected and analyzed material the researcher will perform his interpretations of the result achieved in the research. As one of the possible methods for preparing research, qualitative research can be cited, which according to Creswell (2014), is based on an investigative process, through text and image analysis to develop the object of search.

The research method to be used in this document will be the case study. The case study was combined with another research methodology to document analysis.

The documentary analysis was carried out in the proceedings in the Labor Court, through access to data available by the 14th Regional Labor Court (TRT 14). This access is done through online software called Electronic Judicial Process (PJe). The PJe software provides access to all the processes in which Fundação Universidade Federal de Rondônia (UNIR) was included, through the search using the CNPJ of UNIR as a filter. After the filter used by UNIR's CNPJ, 68 cases were identified in which UNIR was sued, from January 1, 2015 to December 31, 2019.

The documentary analysis combined with content analysis which, according to Bardin (2010), were used to identify lawsuits, through online research, on the 14th Region TRT website, in which UNIR was ordered to act, through its Attorney's Office, the processes were divided by year in which they were filed. After dividing the processes by year, it was initiated the access to each one of the 68 processes.

From the access to the processes, 15 categories were identified. The categories were classified according to the Decisions and Sentences issued by the Judges of the Labor Courts, the Judgments issued by the Judges of the 14th Regional Labor Court, and through the Judgments issued by the Ministers of the Superior Labor Court.

As the 68 court cases were analyzed, with a specific focus on the analysis of the Decisions, Judgments and Judgments issued, the categories for the division of cases emerged. The categories were identified as: Precatory Letter, Third Party 
Embargoes, Awaiting Hearing, Filing, Extinct Proceedings without the Resolution of the Merits, Withdrawal of the Complainant Action, Extinction of the Deed, Unfounded, Initial Dismissed, Referral to Federal Court for Judgment, Biennial Prescription, Agreements, Convictions, Reversal of the Conviction in Higher Instance.

After analyzing and mapping the processes in the categories, we sought to identify the values of the agreements, the convictions, the processes that are still pending and the convictions reversed at a higher level so that the values that can be estimated of each category. Therefore, through documentary analysis, it is possible to ascertain the implications of any gaps in the supervision of administrative contracts by Fundação Universidade Federal de Rondônia (UNIR).

\section{Diagnosis of the Processes in Which UNIR Appeared as Party}

The starting point of the research was based on the identification of the processes that Fundação Universidade Federal de Rondônia (UNIR) appeared in the passive pole, together with the Labor Court, through access to the online software PJe.

In the period under analysis, January 1, 2015 to December 31, 2019, 68 lawsuits were identified in which UNIR was summoned. The analysis of the number of lawsuits per year highlights the marked reduction in the number of lawsuits in 2017, as shown in Table 1, below.

Table 1. Elaborated by the authors

\begin{tabular}{lllllll}
\hline Year & $\mathbf{2 0 1 5}$ & $\mathbf{2 0 1 6}$ & $\mathbf{2 0 1 7}$ & $\mathbf{2 0 1 8}$ & $\mathbf{2 0 1 9}$ & Totals \\
\hline Court lawsuits & 15 & 25 & 6 & 11 & 11 & 68 \\
\hline
\end{tabular}

Source: TRT of the 14th Region

There is a marked reduction of $76 \%$ (seventy-six percent) of lawsuits in 2017, and the number of lawsuits in 2018 and 2019, 11 (eleven) lawsuits, in each year, levels lower than in 2015 and 2016, which can be deduced that the reduction can be explained by changes in the Consolidation of Labor Laws (CLT).

Law no. 13,467, of June 13, 2017, standardized, among other changes, the possibility of the claimant being sentenced to the payment of succumbing fees, if it is not proved the veracity of the requests formulated in the initial petition. It can be inferred that the change in the CLT's rules promoted a reduction in the number of labor lawsuits, not only for UNIR, but in the short term for the TRT of the 14th Region and in the medium term for the national level.

The reduction in legal proceedings, motivated, among other factors, by the labor reform, the next topic to discuss is the categories that were identified throughout the survey, the categories in which there was no direct cash disbursement by UNIR or contracted companies for the outsourced services, as shown in Table 2, below.

Table 2. Legal actions per year, elaborated by authors

\begin{tabular}{|c|c|c|c|c|c|c|}
\hline CALL US & 2015 & 2016 & 2017 & 2018 & 2019 & Totals \\
\hline Precatory Letter & & & 2 & 1 & & 3 \\
\hline Third Party Embargoes & & & 1 & & & 1 \\
\hline Awaiting Hearing & & & & & 1 & 1 \\
\hline Filling & & 7 & 1 & 1 & & 9 \\
\hline Extinct Proceedings without the Resolution of Merits & 9 & 3 & & 1 & & 13 \\
\hline Withdrawal of the Complainant Action & & 1 & & 1 & 1 & 3 \\
\hline Unfounded & & 4 & 1 & & 1 & 6 \\
\hline Initial dismissed & & 1 & & 1 & 2 & 4 \\
\hline Referral to Federal Court for Judgment & & & & 2 & 4 & 6 \\
\hline Biennial Prescription & & 1 & & & & 1 \\
\hline
\end{tabular}

Source: $14^{\text {th }}$ Regional Labor Court 
The Precatory Letters and Embargoes of Third Parties are incidental processes linked to another process already in progress. The Precatory Letters are used in order to request that another Labor Court carry out some procedure, to optimize public resources, and can be used for the purpose of hearing a witness, or to evaluate some property of the party executed in another District.

Third party embargoes, in turn, are linked to ongoing executions, where the executed party (ies) use these procedural instruments in order to question the validity of the attachment made. It is worth mentioning the lawsuits Precatory Letters and Embargoes of Third Parties, rigorous monitoring by the Attorney General's Office is necessary, so that, in due time, it can make the necessary challenges or present documents, to clarify the facts, to rule out the possibility of UNIR's condemnation.

Among the cases in which UNIR appears on the liability side, in the period under analysis, a case in which there was no first hearing, and another 42 (forty-two) cases allocated in seven different categories in which the Attorney General's Office had to manifest itself, to safeguard the interests of UNIR. However, the judicial demands did not prosper due to the magistrate's judicial determination for the filing of the case to be carried out in nine cases, three cases due to the withdrawal of the complainant action, thirteen cases with extinction proceeding without the resolution of the merits, four cases with initial dismissed, six unfounded cases, six cases sent to the federal court for judgment and one biennial prescription process.

Among the 11 (eleven) categories described up to now, it was not the focus of the work to discuss the decisions and sentences issued. Although UNIR or the Federal Government did not directly use resources to pay indemnities for the listed processes in the period, there is an entire staff working for the process to go through the Courts.

However, they are separate powers, there is a division between Executive Power, Fundação Universidade Federal de Rondônia and the Judiciary Power, represented in this context by the E. 14th Regional Labor Court.

The procedural steps generate a great expense for the government treasures of the Executive Power, given the need for a UNIR representative at the hearings and the other cost of great relevance is the need for the UNIR defense procedural piece to be carried out, which the Federal General, through its Federal Attorneys, is responsible for preparing. Therefore, it is concluded that even if UNIR is not condemned to indemnify the party complaining of the labor judicial demand, there are the costs of defending the lawsuits for the State. These indirect costs must be analyzed, not only from the perspective of public expenditure, to analyze the extent of indirect expenses that the demands cause in different organs of the Executive Power.

The nine agreements signed by the companies contracted by UNIR, from January 2015 to December 2019, totaled $\mathrm{R} \$ 173,316.36$. The Labor Court, due to its specialty, has as principles the conciliation between the parties, so that there are no processes dragging on the appeals, taking years to become final. Reconciliation is encouraged in the Labor Court, given the nutritional nature of most of the indemnities required, since they come from defaulted salary amounts.

However, reconciliations deserve extra attention. In conciliation, the parties formalize an agreement in which the two parties are satisfied with the values defined for the payment. It is worth reflecting on the reasons that led the companies hired to provide services to UNIR, to reconcile and pay amounts to their former employees.

Due to the simple fact that judicial agreements are formulated, there are indications that payments made during the contract period with the outsourced company were not made in compliance with all legal regulations. Thus, it can be inferred that there is a possible failure of UNIR's control systems, which did not identify that outsourced employees were, at some point, being harmed and that non-compliance with the rights for employees could result in a labor liability for UNIR.

During the analysis period, five labor claims were identified in which UNIR was condemned as a subsidiary debtor and was subsequently obliged to pay the claimants via a Small Value or Precatory Request. After the condemnations by the court, having passed several instances of appeals which are mandatory for the Public Power to appeal, it can be deduced an evident failure during the process of analysis and management of contracts.

The conviction shows that there are gaps to be overcome in the management of contracts and in the Institution's internal control systems. The amounts paid through Small Value Requests - RPV and Precatories, in the period under analysis, totaled $\mathrm{R} \$ 73,891.99$.

In the analysis of the processes, flaws were found, for example, the non-payment of unhealthy work and the payment of the degree of irregular unhealthy work, which requires high attention from the contract administration because the unhealthy work must be properly regulated between the parties since the Basic Project or Term of Reference, which 
was used as a guide for the preparation of the Bidding Notice and later for the contract with the company which won the bidding contest.

It happens that there was a defect in the process in which it was not observed by the control systems specified in the current legislation, such as the legal technical opinion of the bidding notice. Since it is not regulated between the parties that the payment of the unhealthy installments must occur, an addendum to the contract is necessary to regulate this possibility and, subsequently, proceed with the realignment of the contract prices.

During the execution phase of the contracts, a succession of errors may occur, in which the internal control systems did not identify during the processing of the administrative process in its different phases, that to have their right guaranteed, the employee has the assistance of the Labor Court, so that their rights are protected. As an example to that described, we have the process 0000990-05.2016.5.14.0005, where UNIR was ordered in a subsidiary way to pay the additional unhealthy claimant throughout the contract at a rate of $40 \%$ on the minimum wage and reflections on $13^{\text {th }}$ salary, holidays $+1 / 3$, FGTS $+40 \%$ and prior notice throughout the contract.

There are also four lawsuits in which UNIR was ordered to pay R \$110,000.00, amounts not settled and updated, and the lawsuits are pending on appeal due to indemnities for the payment of unhealthy additional work, in maximum degree (40\%).

Another highlight is that the Institution was able to revert three convictions in the higher spheres of Labor Justice, totaling R \$44,582.77, making it evident, in the specific case, that UNIR fulfilled its role, drafting a contract in which it met all labor regulations and, above all, efficiently managed the contract, with no extra costs, direct or indirect, for the public funds.

\section{Final Considerations}

This research has achieved its objectives by demonstrating how procedural flows and internal control systems are fundamental for the proper progress of administrative processes. Failure to implement controls in their various nuances, with emphasis on the possible lack of supervision on the outsourced contracts with their employees, may result in labor liabilities for the contractors.

Although there was a reduction in the number of lawsuits after the labor reform, the labor liability generated against Fundação Universidade Federal de Rondônia (UNIR), during the period of analysis of the work, amounted $\mathrm{R} \$ 73,891.99$, showing that there are gaps in controls carried out by UNIR.

To stop the possibility of convictions, the basic project / theoretical framework models must be updated, in addition to a reanalysis of procedural flows, internal control systems and contract management, to minimize the possibilities of entry of lawsuits, in which UNIR may be sentenced in the alternative to pay labor liabilities.

It should be noted that all efforts to be made regarding the reanalysis of the process flows will not be used only to minimize the direct costs of UNIR but are fundamental to mitigate the indirect costs of public administration, both from the Executive Power, as well as from the Judiciary one. Estimating the indirect costs of the federal public administration, in the Executive and Judicial Power, is a limiting factor of the research, since the amount of resources applied for the movement of the public machine for the defense of UNIR in the processes, are difficult to measure, since it is up to the Federal Prosecutor's Office in the State of Rondônia the defense of UNIR. The measurement of indirect costs for the Union in labor lawsuits may be a source of future research.

\section{References}

Barcellos, A. A. M., \& Nogueira, W. L. (2019). Terceirização no setor público de acordo com a Lei No 13.429/17. Revista de Trabalhos Acadêmicos da FAM, 4(1). Retrieved from http://faculdadedeamericana.com.br/revista/index.php/TCC/article/view/414

Bardin, L. (n.d.). Análise de conteúdo (4th ed.). Lisboa: Edições 70.

Creswell, J. W. (2014). Investigação Qualitativa e Projeto de Pesquisa: Escolhendo entre Cinco Abordagens. Penso Editora.

Creswell, J. W., \& Clark, V. L. P. (2013). Pesquisa de Métodos Mistos (2nd ed.). Porto Alegre: Penso.

D'Andréa, C. (2006). Estratégias de produção e organização de informações na web: conceitos para a análise de documentos na internet. Ciência da Informação, $35(3), \quad 39-44$. https://doi.org/10.1590/S0100-19652006000300004

Junior, A., Neves, G., \& Guimarães, A. (2017). As Bases para um Novo Modelo de Admistração Pública Orientada para Resultados: Evolução dos Paradigmas, Novos Princípios e Dimensões Operacionais de Funcionamento. 
Anais do X Congresso CONSAD de Gestão Público, Brasília, DF, Brasil. Retrieved November 6, 2019, from http://consad.org.br/wp-content/uploads/2017/05/Painel-15_01.pdf

Law no. 8.666, June 21, 1993. (1993). It regulates art. 37, subparagraph XXI, of Federal Constitution, and it estabilishes rules for bidding and contracts of Public Administration and other provisions. Retrieved November 3 , 2019, from http://www.planalto.gov.br/ccivil_03/leis/18666cons.htm

Lima, L. V. de A., Rufino, M. A., \& Machado, M. R. (2019). Criando dificuldades para vender facilidades: corrupção, burocracia e crescimento corporativo no Mercosul. Revista De Contabilidade E Organizações, 13, 64-74. https://doi.org/10.11606/issn.1982-6486.rco.2019.158324

Pozzetti, V. C., \& Wolff, F. L. (2019). Garantias dos direitos individuais e sociais do trabalho, no âmbito da $\begin{array}{llllll}\text { terceirização. } & R . & \text { Themis, } & \text { 17(1), 201-242. } & \text { Retrieved } & \text { from }\end{array}$ http://revistathemis.tjce.jus.br/index.php/THEMIS/article/view/692

Sordi, J. O. (2017). Gestão por processos. Saraiva Educação SA.

\section{Copyrights}

Copyright for this article is retained by the author(s), with first publication rights granted to the journal.

This is an open-access article distributed under the terms and conditions of the Creative Commons Attribution license (http://creativecommons.org/licenses/by/4.0/). 